\title{
PENINGKATAN KAPASITAS PRODUKSI DAN MANAJEMEN USAHA PADA UKM KERIPIK SINGKONG DI KECAMATAN RASAU JAYA
}

\author{
Imelda*, Marisi Aritonang \\ Jurusan Sosial Ekonomi Pertanian, Fakultas Pertanian, Universitas Tanjungpura, \\ Jl. Prof. Dr. H. Hadari Nawawi - Pontianak 78115 \\ *Email : imeldasosek@gmail.com
}

\begin{abstract}
ABSTRAK
Mitra pada kegiatan Ipteks bagi Masayarakat (IbM) ini adalah Usaha Kecil Menengah (UKM) keripik singkong di Kecamatan Rasau Jaya, yaitu UKM Keripik Singkong Berendam dan UKM Keripik Singkong Slondok. Permasalahan yang terjadi yaitu: 1) Proses pengirisan singkong menggunakan alat manual dengan kapasitas sedikit dan minimnya peralatan penunjang, 2) Pengemasan produk menggunakan plastik tanpa merek dan belum ada registrasi Pangan Industri Rumah Tangga (PIRT), 3) manajemen usaha belum optimal dan belum ada pembukuan keuangan, 4) Kurangnya kegiatan promosi sehingga pemasaran terbatas pada wilayah Kecamatan Rasau Jaya. Tujuan kegiatan yaitu meningkatkan kualitas dan kuantitas produk dengan, memperbaiki manajemen usaha dan memperluas pangsa pasar. Metode yang digunakan yaitu sosialisasi, pelatihan, penyuluhan dan pendampingan. Solusi yang diberikan meliputi : 1) pelatihan penggunaan alat pengiris singkong otomatis dan penambahan peralatan penunjang, 2) pelatihan pengemasan menggunakan hand sealer, pemberian merek dan pendampingan pengurusan PIRT, 3) pelatihan pembukuan keuangan, 4) pelatihan pembuatan media promosi (blogspot, banner dan kartu nama) dan pendampingan perluasan pangsa pasar ke wilayah Kota Pontianak. Pelaksanaan kegiatan bulan Maret-Oktober 2017. Hasil kegiatan IbM meliputi: 1) Peningkatan kapasitas produksi melalui penggunaan alat pengiris singkong otomatis dan peralatan penunjang, 2) Kemasan produk yang baik dengan merek yang sudah memiliki registrasi PIRT, 3) Adanya pembukuan keuangan 4) Tersedianya media promosi bagi mitra IbM dan perluasan pangsa pasar ke wilayah Kota Pontianak.
\end{abstract}

Kata kunci: UKM, keripik singkong, kapasitas produksi, manajemen usaha, pangsa pasar.

\section{PENDAHULUAN}

Keberadaan Usaha Kecil dan Menengah (UKM) merupakan pilar penting dalam kegiatan perekonomian masyarakat Indonesia karena kemampuan sektor UKM dalam menyerap tenaga kerja dan mengurangi masalah pengangguran yang terbukti lebih efektif dibandingkan dengan industri besar. Keberadaan UKM di wilayah pedesaan mengutamakan pemanfaatan sumber daya alam yang merupakan potensi wilayah sehingga menjadikannya sebagai alternatif peluang usaha yang berprospek untuk dikembangkan.Sektor UKM dikenal sebagai usaha yang bergerak dalam pemenuhan kebutuhan dasar para pelaku usahanya sehingga dapat meminimalisir risiko kerugian usaha. Sektor UKM juga termasuk dalam kategori usaha sederhana sehingga seringkali terkendala dengan 


\section{Peningkatan Kapasitas Produksi dan Manajemen Usaha ... Imelda \& Aritonang}

pengelolaan manajemen dan pengurusan administrasi keuangan (Purnama dan Suyanto, 2010). Untuk meningkatkan daya saing UKM, diperlukan pengelolaan yang baik dan optimal misalnya dengan menambah kapasitas produksi berupa peningkatan adopsi teknologi, penambahan kapasitas mesin, dan peningkatan kualitas sumber daya manusia (SDM).Sebagai suatu usaha, keberadaan UKM memiliki entry barrier yang rendah, karena adanya kemudahan mendapatkan bahan baku utama, penggunaan mesin pendukung yang relatif sederhana, dan ketersediaan SDM. Hal ini menyebabkan tingginya persaingan di antara para pemilik usaha.

Kecamatan Rasau Jaya merupakan salah satu kecamatan di wilayah Kabupaten Kubu Raya yang memiliki potensi sumber daya alam melimpah sehingga berpeluang untuk pengembangan sektor UKM. Data Kecamatan Rasau Jaya mencatat keberadaan industri kecil di wilayah ini sebanyak 47 usaha yang tersebar di enam desa, yaitu 4 usaha di Desa Rasau Jaya Umum, 1 usaha di Desa Bintang Mas, 2 usaha di Desa Rasau Jaya 3, 34 usaha di Desa Rasau Jaya 1, 5 usaha di Desa Rasau Jaya 2, dan 1 usaha di Desa Pematang Tujuh (BPS, 2015). Jenis UKM di Kecamatan Rasau Jaya yaitu industri rumah tangga olahan pangan yang memanfaatkan sumber daya lokal wilayah meliputi keripik umbi-umbian, rengginang, marning jagung, keripik tempe, keripik pisang, kerupuk buah dan lainnya.

Salah satu UKM yang berpotensi untuk dikembangkan di Kecamatan Rasau Jaya yaitu UKM keripik singkong. Singkong atau ubi kayu adalah makanan pokok sumber karbohidrat yang dapat menggantikan beras. Manfaat singkong bagi kesehatan tubuh yaitu sebagai sumber energi dalam tubuh, menurunkan tingkat kolesterol, mencegah anemia dan alzheimer, mengurangi risiko sakit jantung, menyehatkan tulang dan gigi, memperbaiki jaringan tubuh, membantu mengatur denyut jantung dan tekanan darah, mencegah kanker, mencegah sembelit, menurunkan berat badan, menjaga kelancaran metabolisme, menurunkan tingkat gula darah, meningkatkan sistem kekebalan tubuh, serta mengurangi kecemasan dan tingkat stress (Anonim, 2017). Produk olahan singkong yang banyak diminati oleh masyarakat yaitu keripik singkong karena rasanya yang enak, gurih, renyah dan harganya yang terjangkau. Produk keripik singkong bisa dikonsumsi baik sebagai cemilan (makanan ringan) ataupun sebagai lauk pelengkap nasi.

Pengembangan UKM keripik singkong di Kecamatan Rasau Jaya perlu ditingkatkan mengingat keberadaan bahan baku singkong yang mudah diperoleh di wilayah tersebut dan jumlah tenaga kerja yang mendukung. Ketersediaan luas panen komoditi ubi kayu di Kecamatan Rasau Jaya sebesar 991 Ha dengan rata-rata produksi mencapai 127,25 kw/ha (Asriati, 2015).

Kendala yang seringkali ditemui terkait pengembangan UKM yaitu kurangnya modal, manajemen usaha yang belum optimal, kurangnya adopsi teknologi dalam proses pengolahan dan pengemasan serta jangkauan pasar yang belum luas.Kegiatan pengabdian masyarakat ini bermitra dengan pemilik UKM keripik singkong (Ibu Masroh dan Ibu Sukati)yang berlokasi di Desa Rasau Jaya 3 Kabupaten Kubu Raya. Desa Rasau Jaya 3 merupakan salah satu wilayah di areal Kota Terpadu Mandiri (KTM) Rasau Jaya dengan jarak tempuh dari Kota Pontianak sekitar $32 \mathrm{~km}$ dengan akses jalan yang cukup baik dan menggunakan kendaraan roda empat. UKM keripik singkong Ibu Masroh berdiri tahun 2006 dengan jumlah tenaga kerja 3-5 orang tergantung kapasitas produksi. Bahan baku yang biasa digunakan dalam satu kali proses produksi yaitu 20-30 $\mathrm{kg}$ dengan perkiraan output yang dihasilkan yaitu 6-9 kg. UKM keripik singkong Ibu Sukati berdiri tahun 2013 dengan jumlah 


\section{Peningkatan Kapasitas Produksi dan Manajemen Usaha ... Imelda \& Aritonang}

tenaga kerja 2-3 orang tergantung kapasitas produksi. Bahan baku yang biasa digunakan dalam satu kali proses produksi yaitu 10-20 $\mathrm{kg}$ dengan perkiraan output yang dihasilkan yaitu 3-6 kg. Pemasaran produk keripik singkong masih terbatas pada warung dan pasar tradisional di wilayah Desa Rasau Jaya 3.

Kegiatan usaha pembuatan keripik singkong yang dilakukan oleh mitra masih bersifat tradisional karena masih menggunakan peralatan manual, hasil produksi tergantung ketersediaan modal, keterbatasan jangkauan pemasaran dan belum adanya pembukuan keuangan usaha. Tenaga kerja yang digunakan dalam usaha pembuatan keripik singkong yaitu tenaga kerja dalam keluarga. Penggunaan tenaga kerja luar keluarga hanya dilakukan jika menjelang hari raya dimana permintaan keripik singkong meningkat dan perlu tenaga kerja tambahan terutama untuk kegiatan pengirisan singkong. UKM Keripik Singkong milik Ibu Masroh memiliki kapasitas produksi yang lebih tinggi dibandingkan dengan UKM milik Ibu Sukati, hal ini dikarenakan Ibu Masroh memiliki pelanggan tetap sehingga permintaan keripik singkong lebih banyak. Bahan baku singkong diperoleh dari hasil panen usahatani singkong milik mitra IbM yang lokasinya di halaman samping dan belakang rumah. Luas lahan usahatani singkong milik Ibu Masroh yaitu sekitar $300 \mathrm{~m}^{2}$ dan milik Ibu Sukati sekitar $180 \mathrm{~m}^{2}$. Biasanya jika menjelang hari raya atau hari besar, permintaan keripik singkong meningkat sehingga pasokan bahan baku keripik singkong tidak cukup jika hanya mengandalkan hasil panen usahatani singkong. Untuk mengatasi hal ini, mitra IbM biasanya membeli bahan baku singkong dari pasar di Rasau Jaya.

Proses produksi oleh mitra IbM dilakukan setiap hari dengan rincian kegiatan proses produksi dalam pembuatan keripik singkong yaitu: 1) pengupasan singkong, 2) perebusan singkong sampai setengah matang selama kurang lebih 30 menit, 3) pengirisan singkong, 4) perendaman dengan bumbu selama 2 hari, 5) penjemuran selama $1-2$ hari (tergantung sinar matahari) dan 6) pengemasan produk. Berdasarkan hasil survey di lapangan dan wawancara dengan mitra IbM, dapat diidentifikasi beberapa permasalahan mitra yaitu:

1. Permasalahan pada aspek produksi. Proses pengirisan singkong menggunakan alat pengiris manual yang hanya berjumlah 1 buah sehingga memerlukan waktu yang lama dalam melakukan pengirisan singkong. Alat pengiris singkong milik UKM Ibu Masroh sudah dipakai selama 5 tahun sedangkan alat UKM Ibu Sukati sudah dipakai selama 3 tahun. Kendalanya yaitu alat pengiris sering macet dan mata pisaunya sudah seringkali diganti. Proses pengirisan singkong membutuhkan waktu 3-4 jam per satu kali proses produksi.Kendala lainnya yaitu minimnya peralatan penunjang yang digunakan misalnya pisau, baskom dan dandang. Mitra IbM hanya memiliki dandang kecil untuk merebus singkong, sehingga jika melakukan perebusan singkong dalam jumlah banyak tidak bisa dilakukan sekaligus. Biasanya mitra melakukan dua atau tiga kali perebusan singkong sehingga meningkatkan biaya kayu bakar. Alat penunjang seperti pisau dan baskom jumlahnya minim dan masa pakainya sudah lama sehingga perlu penambahan peralatan baru. Pengemasan produk keripik singkong mentah hanya menggunakan kantong plastik (tanpa menggunakan hand sealer), tanpa merek dan label kemasan, serta belum ada registrasi PIRT. Hal ini disebabkan karena kurangnya pengetahuan yang dimiliki oleh mitra terkait cara pengemasan dan pemberian label yang menarik serta 


\section{Peningkatan Kapasitas Produksi dan Manajemen Usaha ... Imelda \& Aritonang}

keterbatasan peralatan untuk kegiatan pengemasan.

2. Permasalahan pada aspek manajemen usaha yang masih dilakukan secara sederhana dan belum menerapkan prinsip administrasi yang tepat untuk pengelolaan usaha. Pemilik UKM Ibu Masroh dan Ibu Sukati belum memiliki pencatatan keuangan khusus terkait kegiatan usaha, sehingga data mengenai pemasukan dan pengeluaran tidak tercatat dengan baik. Permasalahan ini muncul karena kurangnya pengetahuan pengusaha dalam penerapan administrasi pengelolaan usaha serta belum ada pelatihan dan penyuluhan terkait pengelolaan manajemen usaha baik oleh pihak pemerintah maupun instansi terkait di wilayah Kecamatan Rasau Jaya.

3. Permasalahan pada aspek pemasaran. Pemasaran hasil produk terbatas pada wilayah Desa Rasau Jaya dan Kecamatan Rasau Jaya serta belum menjangkau pasar di Kota Pontianak dan kabupaten lainnya di wilayah Kalimantan Barat. Sebagian besar pelanggan membeli dalam jumlah banyak dengan cara mendatangi langsung tempat produksi. Keterbatasan jangkauan pemasaran juga disebabkan karena belum adanya usaha untuk membuka pangsa pasar ke supermarket, dan toko penjualan oleh-oleh khas Kalimantan Barat di wilayah Kota Pontianak. Salah satu kendala untuk memperluas pasar ke supermarket yaitu tidak adanya registrasi PIRT produk dan kemasan yang sangat sederhana (hanya menggunakan kantong plastik tanpa label kemasan). Kendala lainnya yaitu minimnya kegiatan promosi produk keripik singkong sehingga produk ini hanya terkenal dan mudah diperoleh di sekitar tempat produksi (sekitar wilayah Kecamatan Rasau Jaya). Promosi yang dilakukan selama ini hanya menggunakan promosi dari mulut ke mulut tanpa ada usaha untuk pembuatan media promosi misalnya penggunaan blogspot, pembuatan $x$-banner, kartu nama, dan sebagainya.

Melihat permasalahan diatas, maka penting dan akan sangat bermanfaat bagi para mitra untuk bisa mengatasi permasalahan pada aspek produksi, aspek manajemen usaha dan aspek pemasaran sehingga bisa meningkatkan kapasitas produksi, memperluas pangsa pasar, memperbaiki manajemen usaha dan meningkatkan omzet usaha.

\section{METODE PELAKSANAAN}

Metode yang digunakan dalam pelaksanaan kegiatan IbM adalah sosialisasi, pelatihan, pendampingan, monitoring dan evaluasi. Secara rinci metode pelaksanaan kegiatan meliputi :

1. Orientasi dan sosialisasi kegiatan kepada mitra pemilik UKM keripik singkong terkait tujuan dan tahapan pelaksanaan kegiatan, peranan mitra dan tim pelaksana kegiatan serta kesepakatan jadual pelaksanaan kegiatan.

2. Pelatihan dan pendampingan dalam peningkatan kapasitas produk keripik singkong. Bentuk kegiatan yang dilakukan yaitu pelatihan dan pendampingan penggunaan alat pengiris singkong otomatis, penambahan peralatan penunjang, pelatihan pengemasan dan pelabelan, serta pendampingan pengurusan registrasi PIRT di Kantor Dinas Kesehatan Kabupaten Kubu Raya.

3. Pelatihan dan pendampingan dalam perbaikan manajemen UKM keripik singkong. Bentuk kegiatan yang dilakukan yaitu penyuluhan mengenai pentingnya pengelolaan manajemen usaha dan pelatihan pembukuan keuangan usaha.

4. Pelatihan dan pendampingan dalam perbaikan aspek pemasaran. Bentuk kegiatan yang dilakukan yaitu 


\section{Peningkatan Kapasitas Produksi dan Manajemen Usaha ... Imelda \& Aritonang}

pendampingan perluasan pangsa pasar ke toko oleh-oleh di Kota Pontianak dan pelatihan pembuatan media promosi (blogspot, kartu nama dan $x$-banner).

5. Monitoring dan Evaluasi Kegiatan IbM.

Peranan dan partisipasi pemilikUKM sebagai mitra dalam pelaksanaan program kegiatan IbM yaitu: 1) sebagai peserta aktif yang akan menerima transfer ilmu pengetahuan dan teknologi mengenai peningkatan kapasitas produksi, perluasan pangsa pasar dan perbaikan manajemen usaha., 2) sebagai penyedia tempat untuk pelaksanaan kegiatan pelatihan, penyuluhan dan pendampingan, dan 3) sebagai penyedia bahan baku untuk pelaksanaan kegiatan pelatihan, penyuluhan dan pendampingan. Peserta kegiatan IbM ini yaitu pemilik UKM keripik singkong (Ibu Masroh dan Ibu Sukati)yang berlokasi di Desa Rasau Jaya 3 Kecamatan Rasau Jaya. Selain itu juga dilibatkan beberapa orang karyawan sebagai tenaga kerja di UKM tersebut.

\section{HASIL DAN PEMBAHASAN}

\section{Orientasi dan Sosialisasi Kegiatan IbM}

Kegiatan IbM diawali dengan melakukan sosialisasi pelaksanaan kegiatan kepada pengusaha UKM keripik singkong terkait tujuan dan materi kegiatan, tahapan pelaksanaan kegiatan, peranan mitra dan tim pelaksana kegiatan serta kesepakatan jadual pelaksanaan kegiatan.Tim pelaksana IbM menyampaikan mengenai beberapa bentuk kegiatan yang dilaksanakan yaitu pelatihan peningkatan kapasitas produksi melalui penggunaan mesin keripik singkong otomatis dan penambahan alat-alat pendukung lainnya, pendampingan pengurusan PIRT, pelatihan pengemasan dan pemberian label kemasan produk keripik singkong, pelatihan pemanfaatan media promosi (blogspot, leaflet dan kartu nama), pendampingan perluasan pangsa pasar ke Kota Pontianak serta pelatihan pembukuan keuangan usaha. Pada kegiatan orientasi dan sosialisasi ini juga dibahas mengenai penetapan jadwal pelaksanaan kegiatan IbM. Hal-hal yang dibicarakan yaitu tempat pelaksanaan, waktu pelaksanaan, ketersediaan peralatan dan bahan-bahan yang akan digunakan dalam pelaksanaan IbM.

\section{Pelatihan Peningkatan Kapasitas Produk}

Beberapa bentuk kegiatan yang dilaksanakan terkait pelatihan peningkatan kapasitas produk, meliputi:

1. Pelatihan dan pendampingan penggunaan mesinpengiris singkong otomatis. Alat ini memiliki bentuk dan desain yang sederhana serta tidak membutuhkan keterampilan khusus dalam penggunaannya sehingga memudahkan bagi UKM untuk mengoperasikannya. Struturrangka mesin terbuat dari besi dengan empat buah pisau yang terbuat dari baja dan bisa diasah jika sudah tumpul. Tenaga penggerak mesin menggunakan motor listrik $1 / 4 \mathrm{hp}$ dan memerlukan daya sekitar 200 watt dengan kapasitas potongan mencapai $40 \mathrm{~kg} / \mathrm{jam}$. Jika dibandingkan dengan menggunakan alat keripik singkong manual, alat pengiris keripik singkong otomatis bisa menghemat waktu sekitar 2-3 jam untuk kapasitas produksi yang sama. Selain efisiensi waktu, alat ini juga meminimalkan penggunaan tenaga kerja luar keluarga (upahan) karena alat ini hanya membutuhkan operator satu orang. Hasil dari kegiatan ini yaitu peningkatan kemampuan mitra dalam menggunakan mesin pengiris singkong otomatis sehingga bisa memproduksi keripik singkong dengan lebih cepat serta menghemat waktu dan tenaga. 


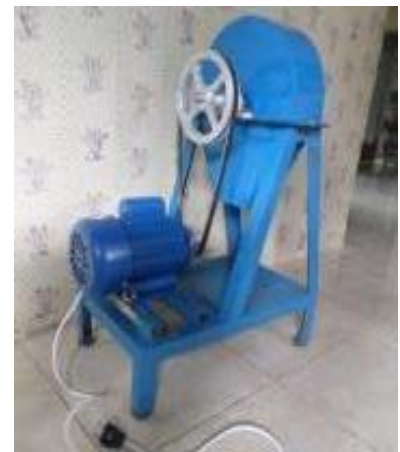

Gambar 1. Pengiris singkong otomatis

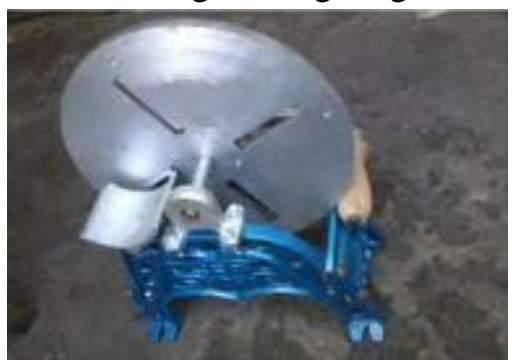

Gambar 2. Pengiris singkong manual

2. Penambahan alat-alat penunjang. Alatalat penunjang yang diberikan kepada mitra IbM yaitu alat-alat yang sering digunakan dalam proses pembuatan keripik singkong meliputi pisau, baskom, keranjang dan dandang besar. Pisau digunakan untuk melakukan pengupasan singkong, baskom sebagai wadah penampungan singkong yang telah dikupas, diiris dan direndam dengan bumbu. Dandang besar dan keranjang digunakan untuk melakukan perebusan dan pengukusan singkong. Hasil dari kegiatan ini yaitu adanya kelengkapan peralatan yang digunakan oleh mitra sehingga kegiatan produksi bisa berlangsung efektif dan efisien.

3. Pelatihan dan pendampingan pengemasan produk, pemberian merek dan label kemasan.Desain kemasan produk keripik singkong harus menarik, inovatif, kreatif, dan memudahkan konsumen untuk membawa dan mengkonsumsinya karena saat ini para konsumen lebih mengutamakan nilai kepraktisannya. Selain itu pengemasan juga menggunakan hand sealer sehingga menjamin kualitas produk. Label merek harus tertera dengan jelas di kemasan produk. Pada label kemasan juga memuat informasi yang singkat dan jelas terkait produk, misalnya informasi bahan baku, tanggal kadaluarsa, nomor registrasi PIRT (Produk Industri Rumah Tangga) serta identitas pengusaha UKM (nama, alamat dan nomor hp). Hasil dari kegiatan ini yaitu: 1)pembuatan merek bagi produk keripik singkong yaitu "Keripik Singkong Berendam" milik Ibu Masroh dan "Keripik Singkong Slondok" milik Ibu Sukati, dan 2) Kemasan produk keripik singkong yang lebih baik dan menarik bagi konsumen.

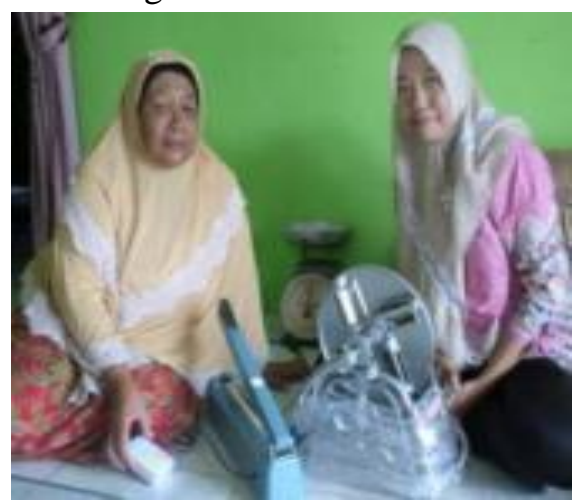

Gambar 3. Pemberian bantuan alat penunjang (Mitra 1)

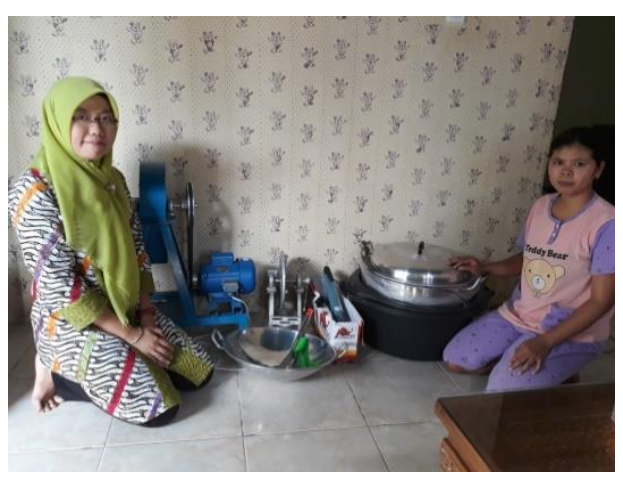

Gambar 4. Pemberian bantuan alat penunjang (Mitra 2) 


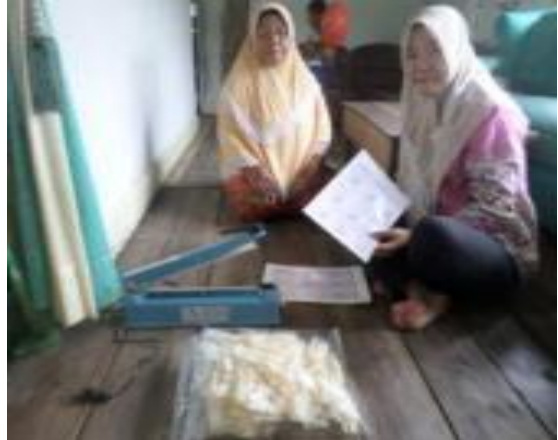

Gambar 5. Pelatihan Pengemasan

4. Pendampingan pengurusan PIRT ke Dinas Kesehatan Kabupaten Kubu Rayasebagai izin jaminan usaha makanan rumahan yang dijual dan beredar di masyarakat yang memenuhi standar keamanan makanan atau izin edar produk pangan. Izin PIRT diberikan kepada produk pangan olahan dengan tingkat resiko yang rendah. Nomor PIRT ini dipergunakan untuk makanan dan minuman yang memiliki daya tahan atau keawetan diatas 7 hari. Nomor PIRT berjumlah 15 digit, berlaku selama 5 tahun dan setelahnya dapat diperpanjang. Lama pengurusan PIRT sekitar 1 minggu sampai 3 bulan, tergantung masing-masing kotamadya/ kabupaten (Jaq, 2013). Adanya registrasi PIRT sebagai jaminan bagi konsumen bahwa produk keripik singkong yang dipasarkan aman untuk dikonsumsi. Hasil dari kegiatan ini yaitu mitra telah mengikuti kegiatan penyuluhan keamanan pangan di Dinas Kesehatan Kabupaten Kubu Raya dan telah memiliki sertifikat PIRT. Sertifikat PIRT yang dihasilkan yaitu No. 2.15.61.12.01.0810.22 tanggal 2 Juni 2017 untuk UKM keripik singkong berendam (kuya) dan Sertifikat No. 2.15.61.12.01.0823.22 tanggal 18 Juli 2017 untuk UKM keripik singkong slondok.

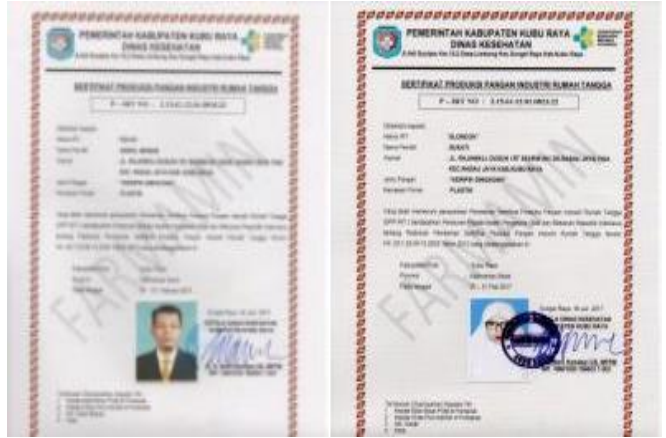

Gambar 6. Sertifikat PIRT

\section{Pelatihan Manajemen Usaha}

Bentuk kegiatan yang dilaksanakan terkait pelatihan manajemen usaha yaitu pelatihan dan pendampingan dalam pembuatan pembukuan keuangan usaha. Pembukuan adalah proses pencatatan yang dilakukan secara teratur untuk mengumpulkan data dan informasi keuangan suatu perusahaan atau organisasi. Pencatatan itu meliputi harta, kewajiban, modal, penghasilan dan biaya, serta jumlah harga perolehan dan penyerahan barang atau jasa, yang ditutup dengan menyusun laporan keuangan berupa neraca dan laporan laba rugi untuk periode tahun tersebut (Anonim, 2015). Manfaat pembukuan keuangan usaha meliputi: 1) Melindungi dana usaha karena tercantum catatan mengenai transaksi dan saldo usaha, 2) Menganalisa sumber penghasilan usaha, 3) Memonitor aliran uang sehingga bisa mengendalikan biaya dan pengeluaran kas, 4) Mengetahui posisi keuangan usaha terkini yakni mengetahui perkembangan usaha dengan cara merekapitulasi dan mengelompokkan datadata dari pembukuan keuangan usaha untuk mengetahui perputaran uang, 5) Pengambilan keputusan usaha yang lebih baik, 6) Meningkatkan performa usaha, dan 7) Merencanakan cashflow untuk keputusan pengambilan tambahan modal dari investor (Kumara,

2012). 


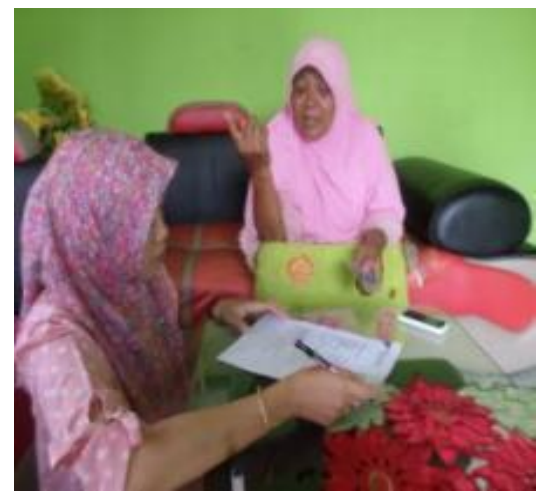

Gambar 7. Pelatihan Pembukuan Keuangan Usaha (Mitra 1)

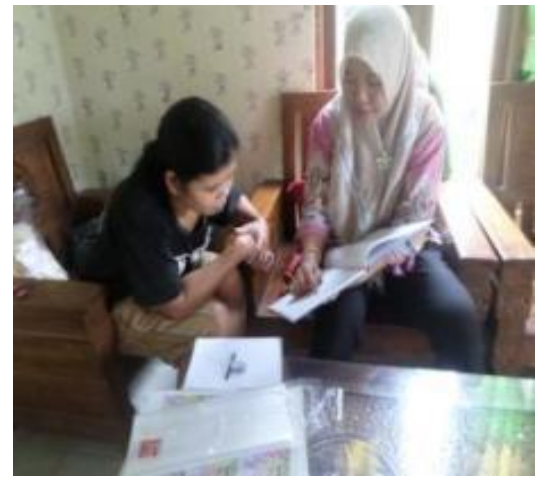

Gambar 8. Pelatihan Pembukuan Keuangan Usaha (Mitra 2)

\section{Pendampingan Perluasan Pangsa Pasar}

Beberapa bentuk kegiatan yang dilaksanakan terkait pendampingan perluasan pangsa pasar, meliputi:

1. Pendampingan untuk membangun jaringan relasi pemasaran dengan supermarket dan toko penjual oleh - oleh di wilayah Kota Pontianak. Hal ini dilakukan dengan tujuan memperluas pangsa pasar untuk wilayah Kota Pontianak, karena selama ini jangkauan pemasaran untuk hasil produk UKM mitra IbM hanya di sekitar wilayah Kecamatan Rasau Jaya.Hasil yang diperoleh yaitu terjalinnya kerjasama antara UKM dengan toko penjual oleh-oleh di Kota Pontianak, sehingga pemilik UKM bisa memasarkan produk keripik singkong di wilayah Kota Pontianak.

2. Pelatihan pembuatan media promosi (blogspot, x-banner dan kartu nama). Pembuatan blogspot dan pendampingan untuk operasionalisasi blogspot. Pemanfaatan blogspot untuk usaha dapat memberikan nilai positif terhadap peningkatan operasional usaha dan dapat dijadikan sebagai salah satu strategi pemasaran produk dan jasa (Anonim, 2015). Blogspot yang telah dihasilkan yaitu

www.keripiksingkongberendam.blogspot .com dan www.keripiksingkongslondok.blogspot.c om. Blogspot berisikan artikel-artikel terkait produk keripik singkong, manfaat singkong dan hasil olahannya bagi kesehatan tubuh, proses pembuatan keripik singkong, dan informasi pemasaran keripik singkong. Selain blogspot, juga dihasilkan x-banner dan kartu nama sebagai media promosi bagi UKM keripik singkong.

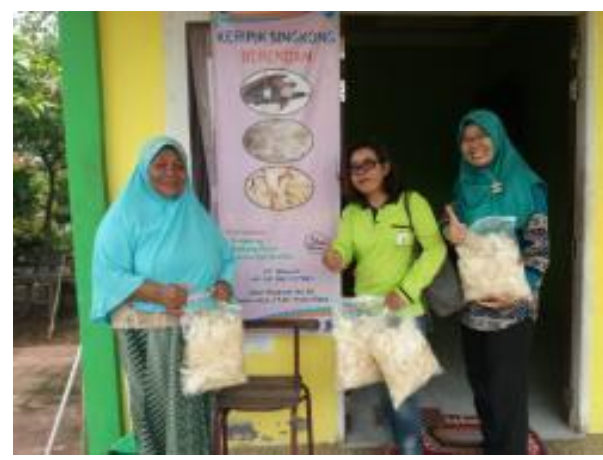

Gambar 9. Tim Pelaksana danMitra

\section{Monitoring dan Evaluasi Kegiatan}

Monitoring dan evaluasi terhadap indikator yang telah ditetapkan. Indikator keberhasilan pelaksanaan IbM meliputi kegiatan evaluasi yaitu pengisian angket (kuisioner) mengenai pelaksanaan kegiatan pelatihan dan penyuluhan serta hasil kegiatan yang telah dilakukan. Data awal produksi dan pendapatan mitra IbM sebelum pelaksanaan kegiatan yaitu produksi sebesar $36 \mathrm{~kg} / \mathrm{bulan}$ dan pendapatan Rp. 418.400,-/bulan. Hasil evaluasi menunjukkan bahwa telah terjadi peningkatan produksi dan pendapatan setelah pelaksanaan kegiatan IbM. Peningkatan 


\section{Peningkatan Kapasitas Produksi dan Manajemen Usaha ... Imelda \& Aritonang}

produksi yang dihasilkan yaitu sebesar 44 $\mathrm{kg} /$ bulan dan peningkatan pendapatan sebesar Rp. 765.600,-/bulan.

Secara keseluruhan, respon mitra IbM dalam pelaksanaan kegiatan IbM yaitu sangat positif, terlihat dari keterbukaan mitra dalam menerima kedatangan tim pelaksana kegiatan serta keterlibatan peserta dalam keseluruhan rangkaian kegiatan.

\section{KESIMPULAN DAN SARAN}

\section{Kesimpulan}

Pelaksanaan kegiatan IbM yang bermitra dengan pemilik UKM keripik singkong di Desa Rasau Jaya 3 Kecamatan Rasau Jaya telah memberikan pengetahuan dan wawasan dalam peningkatan kapasitas produksi, perbaikan manajemen usaha dan perluasan pangsa pasar. Luaran yang dihasilkan dalam kegiatan ini meliputi:

1. Peningkatan kapasitas produksi dan kuantitas produk melalui penggunaan alat pengiris singkong otomatis dan penambahan alat-alat penunjang usaha, meliputi pisau, baskom, keranjang dan dandang besar.

2. Produk keripik singkong dengan kemasan yang menarik, menggunakan hand sealer, dilengkapi dengan merek dan label kemasan serta sudah memiliki nomor registrasi PIRT (Pangan Industri Rumah Tangga).

3. Pemilik UKM mampu melakukan pembukuan keuangan usaha.

4. Perluasan pangsa pasar ke supermarket dan toko penjual oleh-oleh di wilayah Kota Pontianak serta tersedianya media promosi bagi mitra IbM untuk mempromosikan produk yang dihasilkan melalui blogspot, kartu nama, dan $\mathrm{x}-$ banner.

5. Peningkatan produksi yang dihasilkan yaitu sebesar $44 \mathrm{~kg} / \mathrm{bulan}$ dan peningkatan pendapatan sebesar Rp. 765.600,-/bulan.

\section{Saran}

1. Perlunya peranan pemerintah daerah untuk meningkatkan keunggulan kompetitif dan daya saing UKM terutama dalam hal peningkatan kualitas dan kuantitas produk, diversifikasi produk, adopsi teknologi, jaminan pemasaran, pengadaan sarana prasarana UKM serta perbaikan manajemen usaha.

2. Diharapkan adanya kegiatan pengabdian masyarakat lainnya di wilayah Kecamatan Rasau Jaya dengan kelompok mitra pengusaha UKM yang memanfaatkan sumber daya lokal di wilayah tersebut. Hal ini sebagai salah satu cara untuk meningkatkan peranan dan daya saing sektor UKM di Kecamatan Rasau Jaya.

\section{UCAPAN TERIMA KASIH}

Penulis mengucapkan terima kasih kepada Direktorat Riset dan Pengabdian Masyarakat, Direktorat Jenderal Penguatan Riset dan Pengembangan Kementerian Riset, Teknologi dan Pendidikan Tinggi sesuai dengan Kontrak Program Pengabdian Masyarakat Nomor: 023/SP2H/PPM/DRPM/IV/2017 Tanggal 3 April 2017.

\section{DAFTAR PUSTAKA}

Anonim. 2015. Pentingnya Pembukuan Dalam Bisnis. http://www.epaminternational.com/artik el/artikel-bisnis/87-pentingnyapembukuan-dalam-bisnis.html. Diakses tanggal 10 April 2016.

Anonim. 2015. Pentingnya Website Untuk Usaha Kecil Menengah. http://besswonomulyo.blogspot.com/20 15/01/pentingnya-website-untuk-usahakecil.html. Diakses tanggal 10 April 2015. 
Anonim. 2017. 15 Khasiat Singkong Untuk Kesehatan.

https://www.khasiatsehat.com/khasiatdan-manfaat-singkong/. Diakses tanggal 14 Maret 2018.

Asriati, Nuraini. 2015. Pengembangan Kawasan Terpadu Mandiri dengan Pendekatan Model One Village One Product (OVOP) Daerah Transmigrasi Rasau Jaya. Prosiding Seminar Nasional 9 Mei 2015. 706-721.

BPS. 2015. Kecamatan Rasau Jaya dalam Angka Tahun 2015. BPS Kabupaten Kubu Raya.

Jaq. 2013. Cara Mengurus Perizinan PIRT (Pangan Industri Rumah Tangga). http://www.saran2.com/cara-mengurusperizinan-pirt-pangan-industri-rumahtangga.htm. Diakses tanggal 8 April 2016.
Kumara, Amriwansyah. 2012. Apa Pentingnya Pembukuan Untuk Bisnis Kita?

https://annasahmad.wordpress.com/201 2/06/20/apa-pentingnya-pembukuanuntuk-bisnis-kita/. Diakses tanggal 10 April 2016.

Purnama, C. dan Suyanto. (2010). Motivasi dan kemampuan usaha dalam meningkatkan keberhasilan usaha industri kecil (Studi pada industri kecil sepatu di Jawa Timur. Jurnal Manajemen dan Kewirausahaan. Vol. 12. No. 2, September 2010. 177-184. 